\title{
STATE VALUE-ADDED TAX COLLECTION EFFICIENCY IN BRAZIL
}

Otavio Gomes Cabello'

Luiz Eduardo Gaio ${ }^{2}$

Amaury Jose Rezende ${ }^{3}$

\begin{abstract}
Brazil has one of the highest tax burdens on the value added taxes in the world, from where it derives a significant part of the tax collection from the tax system based on consumption. Brazilian tax burden on consumption vary from $7 \%$ to $29.8 \%$ of the Gross Domestic Product, with the world average in $3.88 \%$ and $7.25 \%$ (OCDE, 2012). In 2015, the state VAT (ICMS) represented $20,56 \%$ of all tax revenues collected in Brazil. Previous literature reveals that to have an efficient tax collection it is necessary operational structure and people, and, according to Bird and Jantscher (1992, p. 1), a good tax administration is not the one that collects the most revenue, but also the quality of this collection must be considered. The purpose of this paper is to determine the relative efficiency of Brazilian state value-added tax collection. We used a three-step Data Envelopment Analysis and Stochastic Frontier Analyses method to rank states based on the relative efficiency of their respective tax agencies. The results indicate that Brazil does not have an efficient ICMS collection, and the states have a large difference in collection efficiency. The results can contribute to States to establish management polices to improve their ICMS collection and analyze if there is a moral hazard problem in Brazil. This study can contribute to the tax reform currently in discussion, to Brazilian States to establish management polices to improve their collection and fills in a gap in the public finance/tax literature.
\end{abstract}

Keywords: Tribute. Tax administration. Tax Efficiency. VAT.

\footnotetext{
' otavio.cabello@fca.unicamp.br - Universidade Estadual de Campinas - Campinas-SP, Brasil. https://orcid.org/0000-0003-4933-512X

${ }^{2}$ luiz.eduardo@fca.unicamp.br - Universidade Estadual de Campinas - Campinas-SP, Brasil. https://orcid.org/0000-0003-3106-7649

amauryj@usp.br - Universidade de São Paulo - São Paulo-SP, Brasil. https://orcid.org/0000-0003-3057-6097

- DOI: http://dx.doi.org/10.14392/asaa.2019120302
}

- Artigo submetido em: 27/02/2019. Revisōes requeridas em: 19/11/2019. Reformulado pelos autores em: 30/11/2019. Aceito em: 01/12/2019. 


\section{EFICIÊNCIA DA ARRECADAÇÃO DO ICMS NO BRASIL}

Resumo: O Brasil possui uma das maiores cargas tributárias de tributos estaduais sobre o valor agregado do mundo, de onde deriva uma parte significativa da arrecadação tributária de um sistema tributário baseado no consumo. A carga tributária brasileira sobre o consumo varia de $7 \%$ a $29,8 \%$ do Produto Interno Bruto, com média mundial de 3,88\% e 7,25\% (OCDE, 2012). Em 2015, o ICMS representou 20,56\% de todas as receitas tributárias arrecadadas no Brasil. A literatura anterior revela que, para obter uma arrecadação eficiente de impostos, é necessária estrutura operacional e pessoal e, de acordo com Bird e Jantscher (1992, p. 1), uma boa administração tributária não é a que mais gera arrecadação, mas também a qualidade dessa arrecadação deve ser considerada. $O$ objetivo deste artigo é determinar a eficiência relativa da arrecadação de ICMS dos Estados brasileiros. Utilizamos um método de Análise Envoltória de Dados e Análise Estocástica de Fronteiras em três etapas para classificar os estados com base na eficiência relativa de seus respectivos órgãos de arrecadação. Os resultados indicam que o Brasil não possui uma arrecadação eficiente de ICMS e os Estados apresentam uma grande diferença na eficiência da arrecadação. Os resultados podem contribuir para os Estados estabelecerem políticas de gestão para melhorar sua coleta de ICMS e analisar se há um problema de risco moral no Brasil. Este estudo pode contribuir para a reforma tributária atualmente em discussão, para os Estados brasileiros estabelecerem políticas de gestão para melhorar sua arrecadação e preencher uma lacuna na literatura tributária e de finanças públicas.

Palavras-chave: Tributo. Administração Tributária. Eficiência Tributária. IVA. 


\section{INTRODUCTION}

T ax is a product of interaction between many economic agents in a society, as a result of social policies and economic regulations. Companies and the govern are the two agents inserted in this context, but the first is exposed to tax burden and to the complexity of tax legislation established by the Govern; and the second oversees companies for tax collection in accordance with the legislation. According to Alm and Duncan (2014): "Tax administrations exist largely to ensure compliance with the tax laws, and the effectiveness with which tax agencies fulfill their mission has always been a high priority for governments".

Brazil has one of the highest tax burden on the value added taxes (VAT) in the world, from where it derives a significant part of the tax collection from the tax system based on consumption. Brazilian tax burden on consumption vary from $7 \%$ to $29.8 \%$ of the Gross Domestic Product (GDP), with the world average in $3.88 \%$ and $7.25 \%$ (OCDE, 2012). According to the tax legislation there are four types of VAT, represented by three federal taxes (Pis (Programa de Integração Social), Cofins (Contribuição para Financiamento da Seguridade Social) and IPI (Imposto sobre Produtos Industrializados)), one value-add state tax (ICMS - Imposto de Circulação de Mercadorias e Serviços (ICMS - Brazilian tax on the circulation of goods and services) and one municipal tax (ISSQN (Imposto sobre Serviços de Qualquer Natureza)).

The ICMS it is a kind of Value Added Tax (VAT). The current Brazilian taxation system was introduced by the 1988 Constitution, which granted power to Federal, State and Municipal Governments to collect taxes. Due to the several regulations enacted by each of these governmental instances, Brazilian taxation system is very complex, leading to an environment in which taxpayers are required to comply with many obligations, both comprising tax collection and reporting (accessory obligations). Thus, the States are responsible for collecting one of the taxes of Value-Added Tax, which represents the main source of funds collected from states, and of the amount collected, $25 \%$ must be distributed to the municipalities of the states themselves (DELLOITE, 2010).

This research is focusing only in the state VAT (ICMS) the most representative of all taxes charged in Brazil. In 2015, the state VAT (ICMS) represented 20,56\% of all tax revenues collected in Brazil. (Receita Federal do Brasil, 2016).

There are economic incentives by state treasuries to invest and introduce new legislation to increase fiscal compliance and tax collection. It is worth noting that the average of the highest burden considering the various continents, with Brazil having the highest tax burden of $28.9 \%$ of GDP, Latin America is $20.58 \%$; North America and Europe is $19.36 \%$, Asia is $7.25 \%$, which produces a global average burden of $15.77 \%$, considering the average burden of the continents (OCDE 2012; Delloite, 2003).

For the government to have an efficient tax collection it is necessary operational structure and people, and, according to Bird and Jantscher (1992, p. 1), a good tax administration is not the one that collects the most revenue, but also the quality of this collection must be considered. The authors assert: "accurate measure is the size of the 'compliance gap', that is, the gap between actual and potential tax revenues, and how that gap varies among the different sectors of the taxpaying population". However, this estimation of the "compliance gap" it is not easy to measure to pursue. Alm and Duncan (2014) confirm this affirmation mentioning that:"tax administrators have limited control over such variables as a country's tax capacity, its tax laws, and the willingness of taxpayers to participate in the formal versus the informal sector." Thus, it is possible to affirm that the tax agency efficiency can be measured with variables that are available for the agency. 
The revenues are on one side tax collection efficiency; on the other side, the costs. According to Sandford (1995) apud Alm and Duncan (2014):"the budget cost of collecting individual income, business income, and sales taxes is generally in excess of 1 percent of the revenues from these taxes, and can sometimes be substantially higher". Thus, to determine an efficiency tax collection it is necessary to have available revenues and cost information. However, it is not easy to have information of tax administration costs like administrative information "inputs" (e.g., personnel, materials, information, laws, procedures) to generate "outputs" like tax revenues (Alm and Duncan, 2014). This study has a detailed law information, per state in period over 2011-2014, used a database of company called Systax Fiscal Intelligence (Systax Fiscal Intelligence, it is a private company that maintains an updated database of all legal rules regarding the ICMS of all Brazilian states.) and to have others information it was used public information and the "law of access to information" (Law 12.527/2011); a law that obliges public agencies to provide information.

We have found few studies that show estimates of tax collection efficiency (Alm and Duncan, 2014; Aizenman and Jinjarak, 2008; Bird, Martinez-Vazquez and Togler, 2012) using tax revenues and cost information as variables. All studies are based in cross-country comparison. The research of Bird and Jantscher (1992) does not bring estimation of tax collection efficiency, but has a theoretical approach.

Most part of Brazilian studies about ICMS collection efficiency is focused on tax distribution, harmful tax competition and tax incentive. We did not find any Brazilian research trying to show the ICMS collection efficiency considering the tax administration, in others words, the efficiency of the public machine. Thus, this study tries to fill in a gap in tax and public finance studies in Brazil.

The tax burden in Brazil is heavy, complex and dynamic. In 2015, the tax burden reached $32.66 \%$ of the GDP (Receita Federal do Brasil, 2016). There are 92 types of taxes in Brazil and the Brazilian tax legislation goes through constant modifications. The ICMS represents $20.84 \%$ of the total amount of taxes raised in the year of 2015 (Receita Federal do Brasil, 2016), being the one with the greatest representation in relation to all other taxes. The ICMS, specifically, is administrated by 27 different taxes legislation, due to the fact of being a state and Federal District (FD) tax. One must also consider the dynamism which these rules are altered, making it difficult for companies to follow them, and for the government to reach an efficient revenue collection.

In the presented scenario, the objective of this paper is to determine the relative efficiency of Brazilian state value-added tax collection. The results can contribute to help the states in the development of public polices and internal polices trying to be more efficient. Brazil is going through a deep economic crisis, so any study that tries to indicate some efficiency is important. Other possible contribution it is to the Brazilian tax reform current discussion, mostly in the state VAT.

To accomplish this goal, we used a three-step Data Envelopment Analysis (DEA) and stochastic frontier analyses (SFA) method to rank states based on the relative efficiency of their respective tax agencies used by Alm and Duncan study (2014). The use of this method (three-step DEA) is also a contribution of the study, because there is no study with this approach in the Brazilian tax collection scenario.

\section{BACKGROUND}

The literature on tax collection, tax system and efficiency in collection mention the relationship between government and taxpayers, asserting that public trust is affected by tax administration. In other 
words, depending on how the tax administration is conducted, the taxpayer will have public trust or not (Bird and Jantscher, 1992). Considering value-added tax (VAT) approach, Aizenman and Jinjarak (2008) study shows that greater political instability and polarization tend to reduce tax efficiency. Similarly, economic structures that increase the cost of enforcement, like less urbanization, less trade openness, and higher share of agriculture, reduce the collection efficiency of the VAT.

The Aizenman and Jinjarak (2008) study measures VAT efficiency in 44 countries over the period 1970-1999. However, in the study, VAT collection efficiency was measured not considering the cost of tax administration or administrative variables, but buy using two measures of VAT: (a) C-efficiency (the ratio of the VAT revenue to aggregate consumption, divided by the standard VAT rate) and (b) Efficiency (ratio of VAT revenue to GDP, divided by the standard VAT rate) - crossing with explanatory variables: (a) measures of economic development; (b) composition of GDP and population; (c) measures of political instability and fluidity of political participation. Therefore, it was possible to affirm how these variables influence VAT collection efficiency.

Alm and Duncan (2014) research 28 countries members of OECD, over the period 2007-2011, trying to determine the relative efficiency of tax agencies in their use of inputs. It was used in the study a three-step method which combines data envelopment analysis (DEA) and stochastic frontier analysis (SFA). The variables selected were salary and information technology (IT) administrative costs related to tax functions as inputs; and as outputs, it was used the total tax revenues, and corporate income tax (CIT), personal income tax (PIT), and value-added tax (VAT) revenues separately and in various combinations. The results indicate that 13 of the 28 countries are relatively efficient in collecting any of the three types of tax revenues. Overall, the average efficiency scores range from 0.838 to 0.904 across the various tax revenue measures. According to the authors, these results imply that, on average, countries should be able to collect their current level of revenues with approximately 10 to 16 percent less inputs.

The Bird, Martinez-Vazquez and Togler (2008) study about Latin America countries tried to observe the impact of Corruption and voice/accountability in tax performance. They use tax effort as a dependent variable and corruption and voice/accountability as an independent variable. These empirical results strongly suggest that corruption and voice/accountability play a significant role in the determination of the level of tax effort in developing and transition countries.

This study, differently from Aizenman and Jinjarak (2008), Alm and Duncan (2014) and Bird, Martinez-Vazquez and Togler (2008) research, considers only the VAT revenues and uses other variables to determine the relative efficiency of VAT tax collection. Another difference is that those studies analyze a whole country efficiency and this study is focused in states collection within a country with a continental extension, where there are large differences in: (a) economy; (b) GDP participation; (c) urbanization; (d) share of agriculture, etc.

Another study that uses the same methodology as this one is the Adam, Delis and Kammas (2011), but their study focuses on public sector efficiency in general and not specifically in tax collection efficiency. The study observes public spending and relative public services efficiency, considering, as input variables, public spending on education, health, economic affairs, general public services and social security and welfare; and as output variables measures of public services results: secondary school enrollment, quality of education, life expectancy at birth, infant mortality rate and etc.

A study that evaluate state tax efficiency it was Jha, Mohanty, Chatterjee and Chitkara (1999) study. They measure the tax efficiency in Indian states, in the period of 1980 to 1993, using as tax capacity three variables: (a) state domestic product (SDP); (b) proportion of agricultural income to total SDP (according 
to the authors agriculture is hardly taxed in India); and (c) per capita real rural household consumption expenditure (henceforth $\mathrm{CO}$ ) to proxy the state of poverty conditions and its impact on tax potential. They also use the tax rate average.

According to Jha, Mohanty, Chatterjee and Chitkara (1999) the higher proportion of central government grants in the total expenditure of states, the lower is their efficiency in tax collection; and, ceteris paribus, the less poor states are less inefficient in tax collection. Therefore, the analysis of the study provides a framework to evaluate the temporal trend in Indian states tax efficiency, both inter-state and overall, and to see whether there is evidence of a close relation between central transfers and state tax efficiency. They conclude that is a problem of moral hazard in the design of central government grants to state governments in India, because the results indicate that the greater proportion of states expenditure financed by central grants, the lower is their tax efficiency.

Considering the Brazilian previous literature, Souza and Gasparini (2006) analyzed to what extent the State Participation Fund follows the objectives predicted in the Federal Constitution and the impact on the efficiency of public management. The efficiency was analyzed observing the tax collection of 26 Brazilian States and the Federal District, using Principal Component Analysis (PCA) and DEA. The results show the South region has the best efficiency in tax collection and the Northeast region has the least relative efficiency scores. The results also indicate that the Northeast region has a lack and considerable waste of public resources.

Ribeiro and Costa (2017) studied a Brazilian state collection efficiency after the use of electronic invoice. It was observed the tax collection behavior considering the 2004-2009 period using DEA method. The results indicate the relative efficiency of the states. However, the Ribeiro and Costa (2017) study uses as input total income of the population; total population and car fleet. However, it was not presented the relation between the input variables selected and the output (tax revenues).

Vieira's (2018) study aims to measure the level of efficiency in district fiscal management considering the differences in fiscal benefits provided by States for companies located in their territory. The study considered the industrial, wholesale and distributors companies in 1996 to 2016 period, using DEA. The study uses Purchases Industrialization as input variables and ICMS collected and Employment generate as output variables. The results indicate that district fiscal management police, pursuing the increase of tax collection performance as well as the employment generation, was not enough to accomplish the expected efficiency.

\section{DATA ENVELOPMENT ANALYSIS (DEA)}

The Data Envelopment Analysis (DEA) was developed by Charnes Cooper and Rhodes (1978) to have an indicator which presents the concept of efficiency studied in the 50's. DEA is a mathematic method of analyzes based in linear programming technic. Differing from traditional statistics method, the DEA aims to measure the performance of operational units or decision taking. DEA considers multiples informational inputs and outputs (Mariano, 2008; Oliveira \& Gomes, 2001).

According to Oliveira and Gomes (2001), DEA allows estimates a relative efficiency through the development of a frontier efficiency. There are several technic to estimates the frontiers, according to Mariano (2008) the usually used are: i) CCR (Charnes, Cooper and Rhodes), ii) BCC (Bankers, Charnes and Cooper), iii) FDH (Free Disposal Hull), iv) Additive Variant, v) Additive Invariant, vi) Multiplicative Variant and vii) Multiplicative Invariant.

The efficient frontier considers the relationship between input and output variables. The inputs variables are the inputs used in the production process and the outputs variable correspond to the output 
obtained in the process. To estimate the efficient frontier, the DEA considers the productive units called Decision Making Unit (DMU) (Jubran, 2006)

According to Kassai (2002) DMUs can be business groups, individual companies, departments, divisions or administrative units. In this research DMUs will be the Brazilian States. Kassai (2002) also points out that DMUs must meet the prerequisites: i) the units under analysis must be comparable; (ii) shall act under the same conditions; iii) the factors (inputs and outputs) should be the same for each unit, differing only in intensity or magnitude.

The DEA analysis aims to estimate the efficiency frontier by linear programming. In a simple context that considers only one input for a product, the efficiency measure is expressed by equation 01 .

Efficiency $=$ Product $/$ Input

Companies (DMUs) have multiple inputs and products and efficiency is calculated by the ratio of inputs and outputs, according to equation 02.

$H_{k}=$ Sum of weighted products $/$ Sum of weighted inputs $=\sum_{i}^{n}=1 u_{i} y_{i k} / \sum_{i}^{n}=1 v_{i} y_{i k}$

where $\mathrm{H}$ is the measured efficiency for the evaluated unit $\mathrm{k}, \mathrm{u}$ and $\mathrm{v}$ are the weights, $\mathrm{y}$ is the product vector and $\mathrm{x}$ is the input vector.

The DEA model consider the weights as unknown. The optimization method is used to establish the weights that maximize efficiency. The two most traditional methods are CCR and BCC. According to Niederauer (2002) they differ in orientation, scale returns, discard and measurement types.

The CCR model developed by Charnes, Cooper, and Rhodes (1978) with Constant Returns to Scale (CRS) identifies the sources and estimates of amounts of inefficiencies identified by the overall efficiency assessment.

According to Kassai (2002) the CCR model aims to maximize the production level using maximum observed input consumption. The BCC model, on the other hand, allows to identify increasing, decreasing and constant scale gains. This model distinguishes between technical and scale inefficiency.

The result of the DEA is the construction of the efficiency frontier and the determination of the distance of each company (DMU) at the frontier. Thus, a relative efficiency score is calculated. It is a measure of relative efficiency as it measures the performance of the unit under evaluation when compared to the other units. For this reason, it is sensitive to the inclusion or exclusion of any unit of analysis.

The Constant Returns to Scale (CCR-CRS) model is suitable for units with constant returns to scale. The BCC-VRS (Variable Returns to Scale) model, developed by Banker, Charnes and Cooper in 1984, is suitable for units that work with variable returns to scale.

Souza Junior and Gasparini (2006) points out that in some cases, when there are many variables to be analyzed as input and output, there is a need to employ statistical techniques of dimensionality. Dyson et. al. (2001) comments that the almost immediate consequence of using a large number of variables is the loss of discriminatory power of models. The results generate a very large amount of efficient DMU's.

When a model has several variables, one solution to correct the dimensionality problem is to select variables in DEA using the input and output correlation matrix separately. High correlation variables are discarded, usually by ad hoc criteria. Dyson et. al. (2001) comments that the elimination of either variable may compromise the estimation of the efficiencies verified. Thus, an alternative solution would be to use 
multivariate statistical techniques such as Principal Component Analysis (PCA). By PCA a factor corresponding to the variables with high correlation is created. The factors will be the variables used in the DEA.

\section{SAMPLE AND RESEARCH DESIGN}

\subsection{Sample and variables}

The initial sample consists of 27 public agencies, composed by 26 Brazilian states, as well as the FD. However, the state of Amapá, Tocantins and Espírito Santo did not provide all the information requested. Thus, the final sample consists of 24 public agencies, composed by 23 states, as well as the FD divided by region as Table 1.

Table 1. Sample-Brazilian States

\begin{tabular}{|c|c|c|c|}
\hline STATES & INITIALS & STATES & INITIALS \\
\hline \multicolumn{2}{|l|}{ Midwest } & Rio de Janeiro & RJ \\
\hline Mato-Grosso & MT & São Paulo & $\mathrm{SP}$ \\
\hline Mato Grosso do Sul & MS & Espirito Santo & ES \\
\hline Goiás & GO & \multicolumn{2}{|l|}{ South } \\
\hline Distrito Federal & DF & Paraná & PR \\
\hline \multicolumn{2}{|l|}{ Northeast } & Santa Catarina & SC \\
\hline Maranhão & MA & Rio Grande do Sul & RS \\
\hline Piauí & $\mathrm{Pl}$ & \multicolumn{2}{|l|}{ North } \\
\hline Ceará & CE & Acre & AC \\
\hline Rio Grande do Norte & $\mathrm{RN}$ & Amazonas & AM \\
\hline Paraíba & PB & Pará & $\mathrm{PA}$ \\
\hline Pernambuco & $\mathrm{PE}$ & Rondônia & RO \\
\hline Alagoas & AL & Roraíma & $\mathrm{RR}$ \\
\hline Sergipe & SE & Tocantins & TO \\
\hline Bahia & $\mathrm{BA}$ & & \\
\hline \multicolumn{2}{|l|}{ Southeast } & & \\
\hline Minas Gerias & MG & & \\
\hline
\end{tabular}

Brazil is composed by 25 states and 1 Federal District in a federalism system as State structure. This federalism means that there is a power share and autonomy between states and the central government. As a result of the federative system, the division of competences among federated entities naturally occurs in the tax field, in which there is strict discipline on the spheres of action of the Union, the States, the Federal District and the Municipalities.

ICMS has 27 different tax laws, as it is a tax collected by States and the Federal District (DF). This feature is already representative of complexity, as Gupta and Mills (2003) examined the United States with state income tax laws. The dynamism in which these rules are changed must also be considered, according to Oliveira (2012), in October 2012, 20 changes were made per day in the ICMS legislation. This particularity of Brazil allows to observe more clearly the tax complexity and its consequences for taxpayer and tax collectors.

The ICMS revenues (REV) were selected as the output variable (Adam, Delis and Kammas, 2011; Alm \& Duncan, 2014; Ribeiro \& Costa, 2017; ) and the following input variables per state, as well as FD, over the period 2011-2014. The variables used in the model are described in the table below. 
The tax collection variable as an efficiency variable is highlighted in Lima (2015 p. 187) study where it states: "Efficiency should be assessed as the set of means used in relation to the purpose of collecting taxes, considering expenses, results and respect for taxpayers".

Table 2. Variables selected

\begin{tabular}{|c|c|c|c|}
\hline Variables & Initials & Measure & Position \\
\hline Input & EMP & $\begin{array}{c}\text { Number of tax administration } \\
\text { employees (Alm \& Duncan, 2014) }\end{array}$ & Position in the end of December \\
\hline Input & INI & $\begin{array}{c}\text { Number of infraction notice issued } \\
\text { (quantity) }\end{array}$ & Sum of the year \\
\hline Input & LD & $\begin{array}{c}\text { Number of legal devices (Alm \& } \\
\text { Duncan, 2014) }\end{array}$ & Position in the end of December \\
\hline Input & ADM & $\begin{array}{c}\text { Administration expenses (Adam, } \\
\text { Delis \& Kammas, 2011) }\end{array}$ & Position in the end of December \\
\hline Input & COM & Number of companies & Position in the end of December \\
\hline EV & GPD & $\begin{array}{c}\text { Share of states in the GPD (Bahl, } \\
\text { 1971; Bird, } \\
\text { Martinez-Vazquez \& Torgler 2008) }\end{array}$ & All year \\
\hline EV & OPE & $\begin{array}{c}\text { Openness (Bahl, 1971; Bird, } \\
\text { Aartinez-Vazquez \& Torgler 2008; } \\
\text { alm \& Duncan, 2014) - measured } \\
\text { exports and imports }\end{array}$ & All year \\
\hline
\end{tabular}

Note: EV refers to external variables. (*) The companies of the Simples Nacional tax system was excluded.

Simples Nacional is a special tax system for small companies in Brazil. There are specific rules to adopt this model, like maximum of income in the last 12 months of $R \$ 3.600 .000,00$, and do not have some specifics activities. The tax legislation of this tax system is federal, and the companies in this tax system pay all taxes (federal, state and municipal) in a sum of tax rates, according to the activity.

One of the contributions of this research is the insertion of two new variables for the development of the evaluation model of VAT collection efficiency. The variables "number of companies" (COM) and "number of infraction notice issued" (INI) were selected because they can contribute to ICMS collection and can show the differences between the states.

It is expected that input variables generate tax collection as output, considering the previous literature (Alm \& Duncan, 2014; Adam, Delis \& Kammas, 2011). It is also expected that the two new variables selected will reflect the tax collection, since the variation in the number of companies influences the tax base, as well as the number of infraction notice issued.

Based on the methodology of Souza Júnior and Gasparini (2006), a Principal Component Analysis (PCA) was performed between the input and output variables. The PCA serves as a diagnostic to assess whether there is a problem of dimensionality of input and product spaces.

Table 3 presents the results for Principal Component Analysis where it shows that there is no dimensionality problem. Only the COM and EMP variables had a significant correlation. Considering the characteristic of the COM variable, it was chosen to use it in the model. The number of 5 inputs is satisfactory for use in the DEA.

Table 3. Análise de Componente Principal (ACP)

\begin{tabular}{|c|c|c|c|c|c|c|}
\hline \multicolumn{6}{|c|}{ Eigenvalues (Sum $=6$, Average $=1$ ) } \\
\hline Number & Value & Difference & Proportion & Cumulative Value & Cumulative Proportion & \\
\hline 1 & 3.773567 & 2.682534 & 0.6289 & 3.773567 & 0.6289 & \\
\hline 2 & 1.091033 & 0.360367 & 0.1818 & 4.864601 & 0.8108 & \\
\hline 3 & 0.730667 & 0.418295 & 0.1218 & 5.595268 & 0.9325 & \\
\hline 4 & 0.312372 & 0.238875 & 0.0521 & 5.90764 & 0.9846 & \\
\hline 5 & 0.073497 & 0.054633 & 0.0122 & 5.981136 & 0.9969 & \\
\hline
\end{tabular}




\begin{tabular}{|c|c|c|c|c|c|c|}
\hline 6 & 0.018864 & & 0.0031 & 6 & 1 & \\
\hline \multicolumn{7}{|c|}{ Eigenvectors: } \\
\hline Variable & PC 1 & PC 2 & PC 3 & PC 4 & PC 5 & PC 6 \\
\hline LD & 0.310611 & 0.115461 & 0.910023 & 0.224123 & 0.082978 & 0.070225 \\
\hline EMP & 0.476405 & -0.180563 & -0.262619 & 0.187409 & 0.795856 & 0.054383 \\
\hline ADM & 0.426475 & 0.279506 & 0.02083 & -0.85418 & 0.009358 & 0.099246 \\
\hline $\mathrm{COM}$ & 0.488218 & -0.134859 & -0.215985 & -0.85418 & -0.497685 & 0.617399 \\
\hline INI & 0.047328 & 0.921482 & -0.213586 & 0.318488 & 0.036351 & -0.01602 \\
\hline VER & 0.504064 & -0.092878 & -0.100933 & 0.125111 & -0.33261 & -0.77513 \\
\hline \multicolumn{7}{|c|}{ Ordinary correlations: } \\
\hline & LD & EMP & ADM & $\mathrm{COM}$ & INI & REV \\
\hline LD & 1 & & & & & \\
\hline EMP & 0.379078 & 1 & & & & \\
\hline ADM & 0.489324 & 0.65828 & 1 & & & \\
\hline $\mathrm{COM}$ & 0.427674 & 0.932486 & 0.672561 & 1 & & \\
\hline INI & 0.052034 & -0.034709 & 0.268939 & 0.009733 & 1 & \\
\hline REV & 0.51771 & 0.930919 & 0.746286 & 0.971569 & 0.024192 & 1 \\
\hline
\end{tabular}

The ICMS revenues data were collected in the website of Conselho Nacional de Política Fazendária (CONFAZ - National Council of Finance Policy). It is important to mention that, since the collection of this tax is under state responsibility, each of the Brazilian states has specific regulations concerning ICMS calculation, rates, payments and accessory obligations. Therefore, companies that operate in different states are subject to several different compliance requirements. The ICMS is collected by most states at the rate of $17 \%$, except for the states of São Paulo and Minas Gerais, whose tax rate is $18 \%$, and Rio de Janeiro, whose tax rate is 19\% - special rates apply to interstate sales (Delloite, 2010).

The number of companies and share of states in the GPD were collected in the website of Instituto Brasileiro de Geografia e Estatística (IBGE - Brazilian Institute of Geography and Statistics). The number of legal devices were handed over by Systax Fiscal Intelligence, which is a private company that maintains an updated database of all legal devices of the ICMS of all Brazilian states. The variable openness was collected in the website of Federal Ministry of Industry, Foreign Trade and Services; and, lastly, the number of tax administration employees and number of infraction notice issued were collected requesting (over period November 2016 to January 2017) for all states by the "law of access to information".

It was selected the period of the last five years, trying to seek the efficiency in the period of pre-crises and crises period (last year - 2014). However, it was not possible to collect data from 2015 from IBGE. They claimed that not all companies are compiled in the system. Thus, it was used the period of 2011 to 2014 (4 years).

\subsection{Research Design}

It was used a three-step DEA/SFA method to rank states based on the relative efficiency of their respective tax agencies adapted from Alm and Duncan (2014) study. This methodology was developed by Fried et al. (2002).

In the first stage, we used DEA (CRS approach) to measure the relative efficiency of ICMS collection efficiency. Alm and Duncan (2014, p. 6) assert that: "this approach is favored because it can deal with production processes that have multiple inputs and outputs, and it imposes no parametric assumptions on the data"; and they complete: "for these reasons, DEA has been used in public finance studies and taxation". According to the authors, DEA was chosen for the first stage because it is better than SFA, since it is well suited for estimating efficiency scores in a small sample, such as this research. 
Nevertheless, because DEA eliminates non-discriminatory variables, a second stage regression analysis is needed to identify key variables that may affect a unit's ability to carry out its mandatory function. These variables define the environment within which each unit must operate and are outside of the tax agency's control. The second stage results allow to repeat the first stage using the adjusted inputs in a third stage estimation, where the adjustments are determined by the second stage estimates. (Alm and \& Duncan, 2014)

In the first stage, it was used the variables $L D, E M P, I N I$ and ADM. These variables represent internal variables and are controlled by the tax agencies, called "decision making units" (DMU). According to Alm and Duncan (2014), the variables of the first stage must represent operating conditions of the agencies and the minimum variable must be selected as input and output, because many inputs and outputs reduce discriminatory power (considering a small sample).

It was used the input oriented CRS (Constant Returns to Scale) model. In the case, the inputs are considered as fixed and the targets for the path to efficiency.

The model can be, in a simple way, described as follows:

$$
\operatorname{Max} \theta_{\mathrm{o}}=\sum_{\mathrm{i}=1}^{\mathrm{s}} \mathrm{v}_{\mathrm{i}} \mathrm{y}_{\mathrm{ik}}(03)
$$

Subject to

$$
\begin{aligned}
& \sum_{\mathrm{i}=1}^{r} \mathrm{v}_{\mathrm{i}} \mathrm{x}_{\mathrm{i} 0}=1 \\
& \sum_{\mathrm{j}=1}^{s} \mathrm{u}_{\mathrm{j}} \mathrm{y}_{\mathrm{j} 0}=1+\sum_{\mathrm{i}=1}^{r} \mathrm{v}_{\mathrm{i}} \mathrm{x}_{\mathrm{ik}} \leq 0, \forall \kappa \\
& \mathrm{v}_{\mathrm{i}} \mathrm{u}_{\mathrm{j}}^{\geq 0, \forall \mathrm{i}, \mathrm{j}}
\end{aligned}
$$

where $\theta$ is the efficiency of DMU $o$; $v_{i}$ and $u_{j}$ are the inputs and outputs weights of $i, i=1, \ldots, r$, and $j, j=1$, $\ldots, s ; x_{i k}$ and $y_{j k}$ are i inputs and $j$ outputs of DMU $k, k=1, \ldots, n ; x$ and $y$ are $i$ inputs and $j$ output of DMU $o$.

I In the second stage, the external variables COM, GDP and OPE were used to create adjusted inputs to the third stage. This step is needed because the environment can distort the real efficiency. According to Alm and Duncan (2014) "The DEA procedure estimates relative efficiency scores that do not account for nondiscriminatory factors, mainly factors that define the operating "environment" of tax agencies and that are largely outside of their direct control." Therefore, this makes the use of DEA score comparisons across units misleading since a unit with a favorable environment is more likely to outperform comparing to a unit with a less favorable environment, all else equal. They address this issue by using the first stage results to estimate a stochastic frontier analysis (SFA) model that allows to adjust for factors outside the control of the DMUs.

As it was discussed previously, the difference between this research and Alm and Duncan (2014) is the sample (countries vs. states), however, considering the territorial extension of Brazil and their differences, environmental variables are required.

The SFA model is expressed as follow:

$$
\theta_{o j}=f\left(z_{j}, \beta\right)+e_{o j}(04)
$$

where $\theta_{\mathrm{oj}}$ is the efficiency score of DMU o obtained in the first stage, $f(z, \beta)$ is the stochastic frontier with the external variables, $e_{\mathrm{oj}}$ is the composite error structure $\left(\mathrm{v}_{\mathrm{oj}}+\mathrm{u}_{\mathrm{oj}}\right)$. It was assumed the Cobb Douglas function, $v_{\mathrm{oj}} \sim\left(\mathrm{N}, \sigma_{\mathrm{v} j}^{2}\right)$ reflects the statistical noise and $\mathrm{u}_{\mathrm{oj}}>0$ reflects the inefficiency term. 
The adjusted inputs are constructed from the results of SFA as follow:

$X^{A}{ }_{o j}=X_{o j}+\left[\max _{j}\left\{z_{j^{\prime}} \bar{\beta}\right\}-z_{j^{\prime}} \bar{\beta}\right]+\left[\max _{j}\left\{v_{o j}\right\}-v_{o j}\right]$

T where $\mathrm{X}_{\mathrm{oj}}{ }_{\mathrm{j}}$ is adjusted input, $\mathrm{X}_{\mathrm{oj}}$ is observed input.

In the third stage estimation, using the adjusted inputs from stage 2 , it was determined the relative tax collection efficiency in the agencies (Brazilian states tax administrations). The relative efficiency scores, obtained in this stage, reproduce pure managerial efficiency. This comparison is possible because the inputs have been adjusted for both environmental factors and statistical noise (Alm and Duncan, 2014).

\section{EMPIRICAL RESULTS}

Table 4 reveals the summary statistic. In Table 34, it is possible to observe a great dispersion in the variables revealing the big differences between Brazilian states. The results of Table 4 reveals differences in virtually all variables; the mean of number of legal devices increase every years, showing a public concern and making more compliance; on the other hand, the number of tax administration employees decreases in the same period, showing a mismatch between increased complexity and less tax inspection. The decrease in the number of companies in 2014 is also observed, revealing the beginning of the economic crises and in the same way a decrease in the number of infraction notice issue, in other words, less companies results in less infraction notice issue. However, it is observed that the States did not follow this decrease, reducing the expenses with administration.

These differences observed in Table 4 reveals the three-steps DEA uses.

Table 4. Summary Statistics

\begin{tabular}{|c|c|c|c|c|c|c|c|c|}
\hline & \multicolumn{2}{|c|}{2011} & \multicolumn{2}{|c|}{2012} & \multicolumn{2}{|c|}{2013} & \multicolumn{2}{|c|}{2014} \\
\hline & $\begin{array}{l}\text { Mean (Stand. } \\
\text { Desv.) }\end{array}$ & Max. (Min.) & $\begin{array}{l}\text { Mean } \\
\text { (Stand. } \\
\text { Desv.) }\end{array}$ & Max. (Min.) & $\begin{array}{l}\text { Mean } \\
\text { (Stand. } \\
\text { Desv.) }\end{array}$ & Max. (Min.) & $\begin{array}{l}\text { Mean (Stand. } \\
\text { Desv.) }\end{array}$ & Max. (Min.) \\
\hline \multicolumn{9}{|l|}{ Inputs } \\
\hline $\mathrm{N}^{\circ}$ of Legal Devices & $\begin{array}{l}372472 \\
(36247)\end{array}$ & $\begin{array}{c}500059 \\
(333040)\end{array}$ & $\begin{array}{l}406973 \\
(35778)\end{array}$ & $\begin{array}{c}534397 \\
(363182)\end{array}$ & $\begin{array}{l}491750 \\
(42394)\end{array}$ & $\begin{array}{c}626882 \\
(389166)\end{array}$ & $\begin{array}{l}498616 \\
(47042)\end{array}$ & $\begin{array}{c}633705 \\
(377417)\end{array}$ \\
\hline № of Employees & $1630(1780)$ & $9409(351)$ & $1576(1669)$ & $8791(361)$ & $1536(1591)$ & $8348(356)$ & 1495 (1509) & $7861(357)$ \\
\hline $\begin{array}{l}\text { № Infraction Notice } \\
\text { Issue }\end{array}$ & $\begin{array}{c}17874 \\
(36761)\end{array}$ & $\begin{array}{c}173799 \\
(644)\end{array}$ & $\begin{array}{c}27669 \\
(72645)\end{array}$ & 346508 (539) & $\begin{array}{l}25494 \\
(62698)\end{array}$ & $306462(336)$ & $18960(33874)$ & $150492(413)$ \\
\hline$N^{\circ}$ of companies & $\begin{array}{c}65175,58 \\
(112612,77)\end{array}$ & $\begin{array}{c}553310 \\
(2146)\end{array}$ & $\begin{array}{c}63659,46 \\
(107962,04)\end{array}$ & $\begin{array}{l}531174 \\
(2114)\end{array}$ & $\begin{array}{c}65986,25 \\
(110863,91)\end{array}$ & $544143(2270)$ & $\begin{array}{c}48213 \\
(90379,50)\end{array}$ & $\begin{array}{l}448147 \\
(1001)\end{array}$ \\
\hline $\begin{array}{l}\text { Administrative } \\
\text { Expenses* }\end{array}$ & $943,5(714,4)$ & $\begin{array}{l}3,528,5 \\
(177,1)\end{array}$ & $\begin{array}{l}1,102,7 \\
(866,7)\end{array}$ & $\begin{array}{l}3,863,5 \\
(199,8)\end{array}$ & $\begin{array}{c}1,307,3 \\
(1,194,9)\end{array}$ & $5,559,0(196,4)$ & $\begin{array}{l}1,348,5 \\
(948,5)\end{array}$ & $\begin{array}{l}4,354,8 \\
(189,3)\end{array}$ \\
\hline \multicolumn{9}{|l|}{ Outputs } \\
\hline Total of Revenue* & $12,7(21,70)$ & $\begin{array}{c}107,7 \\
(421,4)\end{array}$ & $13,2(22,5)$ & $111,8(460,2)$ & $14,8(24,6)$ & $121,9(522,9)$ & $15,6(24,8)$ & $22,8(606,9)$ \\
\hline \multicolumn{9}{|c|}{ Environmental Variables } \\
\hline GDP share & $\begin{array}{c}4.05 \% \\
(6.72 \%)\end{array}$ & $\begin{array}{l}32.6 \% \\
(0.20 \%)\end{array}$ & $\begin{array}{l}4.05 \% \\
(6.63 \%)\end{array}$ & $\begin{array}{l}32.1 \% \\
(0.20 \%)\end{array}$ & $\begin{array}{l}4.07 \% \\
(6.58 \%)\end{array}$ & $31.9 \%(0.20 \%)$ & $4.1 \%(6.62 \%)$ & $\begin{array}{l}32.2 \% \\
(0.20 \%)\end{array}$ \\
\hline Openess & $\begin{array}{l}49.48 \% \\
(22.87 \%)\end{array}$ & $\begin{array}{l}93.17 \% \\
(6.70 \%)\end{array}$ & $\begin{array}{l}49.87 \% \\
(22.03 \%)\end{array}$ & $\begin{array}{l}91.54 \% \\
(6.87 \%)\end{array}$ & $\begin{array}{l}47.99 \% \\
(23.06 \%)\end{array}$ & $\begin{array}{l}93.45 \% \\
(6.97 \%)\end{array}$ & $\begin{array}{l}46.32 \% \\
(21.92 \%)\end{array}$ & $\begin{array}{l}93.65 \% \\
(6.80 \%)\end{array}$ \\
\hline
\end{tabular}

${ }^{*} R \$$ millions of reais (Brazil currency)

Considering that stage 1 does not reveal the real efficiency, because the environment is not considered, and the stage 2 is a procedure of adjustment, the discussion is focused on stage 3. Table 5 reveals the relative efficiency measured in stage 3 . 
Table 4. Summary Statistics

\begin{tabular}{|c|c|c|c|c|c|c|c|c|c|c|}
\hline \multirow{2}{*}{ States } & \multicolumn{2}{|c|}{2011} & \multicolumn{2}{|c|}{2012} & \multicolumn{2}{|c|}{2013} & \multicolumn{2}{|c|}{2014} & \multicolumn{2}{|c|}{ Average } \\
\hline & Stand & Comp & Stand & Comp & Stand & Comp & Stand & Comp & Stand & Comp \\
\hline \multicolumn{11}{|l|}{ North } \\
\hline Acre & 0.547 & 0.320 & 0.352 & 0.199 & 0.582 & 0.342 & 0.552 & 0.304 & 0.508 & 0.291 \\
\hline Amazonas & 1.000 & 1.000 & 1.000 & 1.000 & 1.000 & 1.000 & 1.000 & 1.000 & 1.000 & 1.000 \\
\hline Pará & 0.786 & 0.625 & 0.862 & 0.487 & 0.952 & 0.560 & 0.873 & 0.481 & 0.868 & 0.538 \\
\hline Rondônia & 0.500 & 0.449 & 0.447 & 0.454 & 0.438 & 0.371 & 0.347 & 0.242 & 0.433 & 0.379 \\
\hline Roraima & 0.385 & 0.225 & 0.391 & 0.221 & 0.468 & 0.275 & 0.502 & 0.277 & 0.436 & 0.250 \\
\hline \multicolumn{11}{|l|}{ Northeast } \\
\hline Maranhão & 0.522 & 0.387 & 0.835 & 0.747 & 0.599 & 0.424 & 0.600 & 0.473 & 0.639 & 0.508 \\
\hline Piauí & 0.339 & 0.199 & 0.405 & 0.229 & 0.340 & 0.200 & 0.297 & 0.163 & 0.345 & 0.198 \\
\hline Ceará & 0.518 & 0.303 & 0.562 & 0.476 & 0.564 & 0.340 & 0.566 & 0.390 & 0.552 & 0.377 \\
\hline Rio Grande do Norte & 0.650 & 0.506 & 0.678 & 0.635 & 0.666 & 0.521 & 0.579 & 0.479 & 0.643 & 0.535 \\
\hline Paraíba & 0.538 & 0.315 & 0.530 & 0.299 & 0.558 & 0.328 & 0.457 & 0.357 & 0.521 & 0.325 \\
\hline Pernambuco & 0.770 & 0.677 & 0.820 & 0.770 & 0.805 & 0.686 & 0.637 & 0.577 & 0.758 & 0.677 \\
\hline Alagoas & 0.514 & 0.301 & 0.475 & 0.269 & 0.374 & 0.284 & 0.423 & 0.233 & 0.447 & 0.272 \\
\hline Sergipe & 0.457 & 0.324 & 0.472 & 0.267 & 0.492 & 0.409 & 0.330 & 0.182 & 0.438 & 0.295 \\
\hline Bahia & 1.000 & 0.884 & 1.000 & 0.679 & 1.000 & 0.689 & 0.865 & 0.593 & 0.966 & 0.711 \\
\hline \multicolumn{11}{|l|}{ Southeast } \\
\hline Minas Gerais & 1.000 & 0.726 & 1.000 & 0.776 & 1.000 & 0.729 & 1.000 & 0.982 & 1.000 & 0.803 \\
\hline Rio de Janeiro & 1.000 & 0.829 & 1.000 & 0.865 & 1.000 & 0.853 & 0.790 & 0.670 & 0.948 & 0.804 \\
\hline São Paulo & 1.000 & 0.764 & 1.000 & 0.739 & 1.000 & 0.739 & 1.000 & 0.667 & 1.000 & 0.727 \\
\hline \multicolumn{11}{|l|}{ South } \\
\hline Paraná & 0.928 & 0.543 & 0.844 & 0.477 & 0.824 & 0.484 & 0.836 & 0.460 & 0.858 & 0.491 \\
\hline Santa Catarina & 0.809 & 0.582 & 0.728 & 0.511 & 0.757 & 0.485 & 0.607 & 0.341 & 0.725 & 0.480 \\
\hline Rio Grande do Sul & 0.890 & 0.607 & 0.868 & 0.623 & 1.000 & 0.644 & 0.997 & 0.619 & 0.939 & 0.623 \\
\hline \multicolumn{11}{|l|}{ Midwest } \\
\hline Mato Grosso & 1.000 & 0.725 & 0.909 & 0.514 & 1.000 & 0.672 & 1.000 & 0.599 & 0.977 & 0.627 \\
\hline Mato Grosso do Sul & 0.757 & 0.688 & 0.937 & 0.871 & 0.801 & 0.707 & 1.000 & 0.824 & 0.874 & 0.772 \\
\hline Goiás & 0.895 & 0.524 & 1.000 & 0.565 & 1.000 & 0.588 & 1.000 & 0.573 & 0.974 & 0.563 \\
\hline Distrito Federal & 0.628 & 0.437 & 0.704 & 0.491 & 0.667 & 0.579 & 0.532 & 0.428 & 0.633 & 0.484 \\
\hline Average & 0.726 & 0.539 & 0.742 & 0.549 & 0.745 & 0.538 & 0.700 & 0.496 & 0.728 & 0.531 \\
\hline
\end{tabular}

Observing the average of all country $(0,531)$ it is possible to assert that Brazil is not an efficient ICMS collector, or the Brazilian states, in average, have roughly 50 per cent of ICMS collection efficiency. This result reveals that ICMS tax collection in Brazil can increase virtually in 50 percentage points, considering the inputs and output used in the modeling. One reason for this result can be supported by the Aizenman and Jinjarak (2008) asserting, that greater political instability and polarization tend to reduce tax efficiency.

Amazonas, in average $(1,00)$ considering all years, is the most efficient in ICMS collection considering all states researched, followed by Rio de Janeiro $(0,804)$ and Minas Gerais $(0,803)$. Amazonas was the only states that reached all years with $100 \%$ of efficiency. On the other hand, the least efficient states in ICMS collection, in average, is Piauí $(0,198)$, followed by Roraima $(0,250)$ and Alagoas $(0,272)$.

Analyzing individually the regions, it is possible to observe that in the North, excluding Amazonas (most efficient State), Pará reveals to be the most efficient in tax collection; in Northeast, Bahia, followed by Pernambuco, represents the States with best tax collection; in the Southeast, Minas Gerais and Rio de Janeiro are virtually tied in efficiency; in the South, Rio Grande do Sul was the most efficient; and in the Midwest Mato Grosso do Sul, followed by Mato Grosso are the States with best efficiency in tax 
collection. Considering all results, individualized by region, it is observed that richer and larger States are more efficient.

Table 6 established a ranking according to Table 5 `s average compose results.

Table 6. Ranking of ICMS Collection Efficiency in Brazil

\begin{tabular}{|c|c|c|c|}
\hline States & $\begin{array}{c}\text { Average } \\
\text { Comp }\end{array}$ & States & $\begin{array}{c}\text { Average } \\
\text { Comp }\end{array}$ \\
\hline Amazonas & 1.000 & Maranhão & 0.508 \\
\hline Rio de Janeiro & 0.804 & Paraná & 0.491 \\
\hline Minas Gerais & 0.803 & Distrito Federal & 0.484 \\
\hline Mato Grosso do Sul & 0.772 & Santa Catarina & 0.480 \\
\hline São Paulo & 0.727 & Rondônia & 0.379 \\
\hline Bahia & 0.711 & Ceará & 0.377 \\
\hline Pernambuco & 0.677 & Paraíba & 0.325 \\
\hline Mato Grosso & 0.627 & Sergipe & 0.295 \\
\hline Rio Grande do Sul & 0.623 & Acre & 0.291 \\
\hline Goiás & 0.563 & Alagoas & 0.272 \\
\hline Pará & 0.538 & Roraima & 0.250 \\
\hline Rio Grande do Norte & 0.535 & Piauí & 0.198 \\
\hline
\end{tabular}

Considering the average of the region in all years, it is possible to observe the least and the most efficient states per region in ICMS collection efficiency in Table 7.

Table 7. Poorest and Greatest States in ICMS collection efficiency per regio
\begin{tabular}{|c|c|c|}
\hline Region & Least Efficient & Most Efficient \\
\hline North & Roraima & Amazonas \\
\hline Northeast & Piauí & Bahia \\
\hline Southeast & São Paulo & Rio de Janeiro \\
\hline South & Santa Catarina & Rio Grande do Sul \\
\hline Midwest & Distrito Federal & Mato Grosso do Sul \\
\hline
\end{tabular}

It is important to highlight that Espírito Santo, Amapá and Tocantins states are not on the sample.

Considering the inputs selected in the model, the state of Amazonas can raise more income tax with less sources available, in other words, have the most efficient collection. This results probably can be address, because Amazonas have a considerable difference in taxes comparing to other states (federal and VAT). The state of Amazonas gives a discount in the VAT in the import of feedstock, and this, combine with other federal incentives, privilege big companies, mostly because of the big investment necessary to operate in the state, considering the distance of the consumer states and Brazilian seaport. Thus, they have feel huge companies, who pay a lot of taxes, with a few resources available for collection.

In the Alm and Duncan (2014) study, Brazil was not considered in the sample and they consider three types of tax revenues as output (corporate income tax, personal income tax and value-added tax), so it is not possible to establish any kind of comparison.

The results are not complete consistent with Aizenman and Jinjarak (2008) study, because the states which have lowest share GDP they are also less efficient in this research, however, trade openness do not show same behavior. Considering the states with less than $40 \%$ of efficiency (Piauí, Roraima, Alagoas, Acre, Sergipe, Paraíba, Ceará e Rondônia), they all together, have roughly 7,4\% of share in the GDP in the period, and the trade openness an average of $48 \%$ in the period. The most efficient states: Amazonas, Rio de Janeiro, Minas Gerais, Mato Grosso do Sul, São Paulo e Bahia, they, all together, have 
$59,5 \%$ of share in the GDP, and trade openness an average of $46 \%$. Thus, share of GDP it is consistent with Aizenman and Jinkarak (2008) results, but not trade openness.

The reason for this low efficiency, considering the average of the entire country, can probably be addressed to the results of Bird, Martinez-Vazquez and Togler (2008) study, in other words, the high level of corruption and low accountability can contribute to a bad efficiency in collection. However, the study of Bird, Martinez-Vazquez and Togler (2008) focuses in income tax, and maybe these variables do not reflect in VAT collection.

Considering the relation wealth and tax efficiency, in other words, that the poorest states are less efficiency and the richest states are more efficiency, the results also can also be compared to Souza and Gasparini (2006) and also Jha, Mohanty, Chatterjee and Chitkara (1999) results, because the less poor Brazilian states are more efficient in tax collection as Indian states. India and Brazil have some similarity considering the territorial extension, resulting in economics differences between the states; and both are considered emerging countries.

Jha et al. (1999) concludes that is a moral hazard problem in the design of central grants in India, in the period of the analyzes, because higher grants by the central government to the state governments reduce efficiency of tax collection by these states. However, the results of this paper cannot conclude there is the same problem in Brazil, mostly because the system of grants from the central government to the states in Brazil is not similar to India; and it was not considered the variable grants from the central government to the states, only the tax revenues of each state.

\section{CONCLUSION}

The purpose of this paper was to determine the relative efficiency of ICMS tax collection in the Brazilian states. The results indicate that Brazil in general and in average, does not have an efficient ICMS collection, and the states have a large difference in collection efficiency. The most part of these differences can be explained by share GDP and wealth, as in Aizenman and Jinjarak (2008); Souza and Gasparini (2006) and Jha et al. (1999) studies.

The most efficient states were Amazonas, followed by Rio de Janeiro and Minas Gerais, and the poorest efficient states were Piauí, followed by Roraima, and Alagoas.

These results can contribute to states to establish management polices to improve their ICMS collection and analyze if there is a moral hazard problem in Brazil as Jha et al. (1999) study. For the tax literature in Brazil, this study fills in a gap, because there is no study about this issue with this approach.

The limitation of this study was in not considering the use of specific cost variable such as salaries and investments in technology and urbanization as in Alm and Duncan (2014) and Aizenman and Jinjarak (2008) studies. However we did not find any source to collect these datas.

Considering this, a suggestion for future studies, trying to continue this research, is cross-country comparison using some cost variables, other environmental variables and socioeconomic variables such as: health, education, security, transportation and housing, indicators that represent the "end stage" of taxes, as way to verify the association between and the level of efficiency in the collection of taxes and the level of effectiveness in the application of it.

REFERENCES 
Adam, A., Delis, M., and Kammas, P. (2011). Public sector efficiency: leveling the playing field between OECD countries. Public Choice, 146(1-2), 163-183.

Aizenman, J., and Jinjarak, Y. (2008). The collection efficiency of the Value Added Tax:Theory and international evidence. Journal of International Trade and Economic Development, 17(3), 391-410.

Alm, J., and Duncan, D. (2014). Estimating tax agency efficiency. Public Budgeting and Finance, 34(3), 92-110.

Bahl, R. W. (1971). A regression approach to tax effort and tax ratio analysis. Staff Papers, 18(3), 570-612.

Banker, R., Charnes, A., Cooper, W.W. (1984) Some models for estimating technical and scale inefficiencies in data envelopment analysis. Management Science, 30, 1078-1092.

Bird, R. M., and de Jantscher, M. C. (Eds.). (1992). Improving tax administration in developing countries (Vol. 19). Washington, DC: International Monetary Fund.

Bird, R. M., Martinez-Vazquez, J., and Torgler, B. (2008). Tax effort in developing countries and high income countries: The impact of corruption, voice and accountability. Economic Analysis and Policy, 38(1), 55-71.

Charnes, A.; Cooper, W.W.; Rhodes, E. (1978) Measuring the efficiency of decision making units. European Journal of Operational Research, 2(6), 429-444, 1978. http://dx.doi.org/10.1016/0377-2217(78)90138-8

Delloite. (2010). Upstream taxation and foreign investment - Overview of the Brazilian taxation system. (http://www.deloitte.com.br/publicacoes/2007/Overview_of_the_Brazilian_system.pdf)

Delloite. (2003). Pesquisa Internacional sobre Tributação. (https://www2.deloitte.com/br/pt/pages/tax/ articles/termometro-tributario.html).

Dyson, R. G., Allen, R., Camanho, A. S., Podinovski, V. V., Sarrico, C. S., \& Shale, E. A. (2001). Pitifalls and protocols in DEA. European Journal of Operational Research, 132:245-259

Fried, H., Knox L., Shelton S., and Suthathip Y. (2002). Accounting for Environmental Effects and Statistical Noise in Data Envelopment Analysis. Journal of Productivity Analysis, 17 (1), 157-174.

Gupta, S., \& Mills, L. F. (2003). Does disconformity in state corporate income tax systems affect compliance cost burdens?. National Tax Journal, 355-371. https://ssrn.com/abstract=386580

Jha, R., Mohanty, M., and Chatterjee, S. P. Chitkara (1999). Tax Efficiency in Selected Indian States. Empirical Economics, 24(4), 641-654.

Jubran, A.J. (2006) Modelo de análise de eficiência na administração pública: estudo aplicado às prefeituras brasileiras usando a análise envoltória de dados. Thesis (Doctor em Engineering) University of São Paulo.

Kassai, S. (2007) Utilização da Análise por Envoltória de dados (DEA) na Análise de Demonstrações Contábeis. Thesis (Doctor in Accounting) University of São Paulo.

Lima, L. M. M. de. (2015) A aplicação do dever de eficiência à Administração Pública Tributária e sua relação com a Moral Tributária dos contribuintes. Revista Digital de Direito Administrativo, 2(1), 273-292.

Mariano, E.B. (2008) Sistematização e comparação de técnicas, modelos e perspectivas não-paramétricas de análise de eficiência produtiva. Thesis (Master in Production Engineering). University of São Paulo. Niederauer, C.A.P. (1998) Avaliação dos bolsistas de Produtividade em pesquisa da Engenharia da produção utilizando Data Envelopment Analysis. Thesis (Master in Production Engineering) Federal University of Santa Catarina.

OCDE. (2012). Revenue Statistics in Latin America: 1990-2010. (https://www.oecd.org/ctp/tax-global/ Brazil\%20country\%20note_EN_final.pdf) 
Oliveira, F. (2012, agosto 27). ICMS sofre 20 mudanças ao dia e atrapalha negócios. Folha de São Paulo.

Oliveira, H.C, Gomes, A.P. (2001) Eficiência na agroindústria avícola mineira. In: Congresso de Ciências Humanas, Letras e Artes. Ouro Preto, 2001.

Receita Federal do Brasil. (2016). Carga Tributária 2015. (http://idg.receita.fazenda.gov.br/dados/receitadata/estudos-e-tributarios-e-aduaneiros/estudos-e-estatisticas/carga-tributaria-no-brasil/ctb-2015. pdf/view)

Ribeiro, A. W. de A., \& da Costa, R. F. R. (2017). Eficiência na arrecadação tributária dos estados brasileiros: uma análise utilizando a metodologia por envoltória de dados (dea) e índice malmquist. Tekhne e Logos, 8(2), 44-60.

Souza Júnior, Celso Vila Nova de, \& Gasparini, Carlos Eduardo. (2006). Análise da eqüidade e da eficiência dos estados no contexto do federalismo fiscal brasileiro. Estudos Econômicos (São Paulo), 36(4), 803832. https://dx.doi.org/10.1590/S0101-41612006000400006

Vieira, Kleuber José de Aguiar. (2018) Eficiência da gestão fiscal: um estudo a partir da concessão de regimes especiais do ICMS para os setores industrial, atacadista e distribuidor no Distrito Federal. 2018. 116 f., il. Thesis (Master in Economic) - Universidade de Brasília, Brasília, 2018.

\section{Como referenciar}

Cabello, O. G.; Gaio, L. E.; Rezende, A. J. (2019). Tate value-added tax collection efficiency in Brazil. Advances in Scientific and Applied Accounting, 12(3), Set. / Dez. p. 022-038 